\title{
Establishment of Innovative Shared Departments to Advance Interdisciplinary Education
}

\section{Dr. Ronald S. Harichandran, University of New Haven}

Ron Harichandran is Dean of the Tagliatela College of Engineering and recently served as PI on two grants related to the development of technical communication skills and entrepreneurial thinking in engineering students. He led the establishment of the shared Department of Engineering and Applied Science Education in the College of Engineering and partnered with the Dean of the College of Business to establish the university-wide shared Department of Entrepreneurship and Innovation. He has 150 journal, conference proceedings and technical report publications. He is a Fellow of ASCE and has been inducted into the Connecticut Academy of Science and Engineering.

\section{Dr. Brian T. Kench, University of New Haven}

Brian T. Kench is Dean of the AACSB accredited College of Business at the University of New Haven. Dean Kench has built his career around the specialties behavioral and experimental economics, microeconomics, and the economics of organization. He serves as a consultant in the areas of economic damages and economic impact analysis. His works have been published in the Eastern Economic Journal, Journal of Economics and Economic Education Research, Journal of Financial Transformation, and Journal of Regulatory Economics.

\section{Prof. Summer J. McGee, University of New Haven}

Summer McGee, PhD, CPH is Chair of the Department of Health Sciences and Associate Professor of Health Sciences at the University of New Haven. She is also Director of the MS in Healthcare Administration program and Associate Professor of Management in the College of Business at the University of New Haven.

\section{Dr. Michael A. Collura P.E., University of New Haven}

Michael A. Collura, professor of chemical engineering at the University of New Haven, received his B.S. in chemical engineering from Lafayette College and M.S. and Ph.D. degrees in chemical engineering from Lehigh University. After several years in industry, he moved to the academic world, where he has taught engineering for more than 30 years. He is currently the Buckman Professor of Chemical Engineering in the Tagliatela College of Engineering. His professional interests include the application of computers to process modeling and control (particularly for energy conversion processes), engineering education research (student self-assessment, developing conceptual understanding, multidisciplinary learning models), and reform of engineering education.

\section{Dr. Jean Nocito-Gobel, University of New Haven}

Jean Nocito-Gobel, Professor of Civil \& Environmental Engineering at the University of New Haven, received her Ph.D. from the University of Massachusetts, Amherst. She has been actively involved in a number of educational initiatives in the Tagliatela College of Engineering including KEEN and PITCH, PI of the ASPIRE grant, and is the coordinator for the first-year Intro to Engineering course. Her professional interests include modeling the transport and fate of contaminants in groundwater and surface water systems, as well as engineering education reform.

\section{Dr. Charles David Skipton, University of New Haven}

Charles D Skipton, PhD, is the Associate Dean of the College of Business at the University of New Haven and is an Associate Professor of Economics. Dr. Skipton served as a staff Economist for the Joint Economic Committee of the United States Senate in 1999 \& 2000 where he worked on policy issues related to trade openness, trade \& growth, economic freedom \& growth, tax reform, and social security reform, among other topics. Dr. Skipton's research has focused on the measurement of economic freedom in the area of trade policy and the impact of trade openness on long-run economic growth. 


\section{Establishment of Innovative Shared Departments to Advance Interdisciplinary Education}

\section{Introduction}

In recent years, the pursuit of interdisciplinary activities has expanded beyond what can effectively be administered by research centers. The success of innovative curricular models and entrepreneurial activities, for example, requires faculty commitment from multiple departments. The traditional departmental structure fosters competition for students, faculty positions and other resources and does not adequately reward cooperation across departments. Academic initiatives that focus on undergraduate education, for the benefit of students in many programs, require an administrative model that can overcome the barriers to cooperation inherent in the traditional academic department structure. Often interdisciplinary programs are housed in a traditional disciplinary department or college, or in a standalone center reporting to a college dean or the provost. The difficulty of these structures is obtaining broad buy-in from faculty across departments and having disciplinary degree programs include interdisciplinary coursework.

To overcome the difficulties described above, an innovative shared department structure that fosters collaborations to advance interdisciplinary education has been deployed at the University of New Haven. Three shared departments have been established over the last two years: (1) a college-wide department to support interdisciplinary coursework in the first two years of engineering programs; (2) a university-wide department to support entrepreneurship and innovation; and (3) a university-wide department to support health sciences.

The need for each shared department, the administrative and governance structures, and the programs and activities they spearhead are described herein.

\section{The Shared Department of Engineering and Applied Science Education}

\section{The Need}

For over a decade, with initial funding from NSF, engineering faculty at the University of New Haven developed a response to calls for engineering education reform, ${ }^{1}$ which is now called the Multidisciplinary Engineering Foundation Spiral Curriculum (MEFSC). ${ }^{2-6}$ The curriculum, illustrated in Figure 1, consists of 10 multidisciplinary courses (EASC prefix), a subset of which is taken by students across all engineering disciplines, primarily in the first two years. The courses are designed to develop both professional skills and foundational engineering concepts. First year courses are project-based, stressing the development of teamwork, project planning and communication skills. Sophomore level courses present fundamental engineering topics with multidisciplinary applications and stress the integration of engineering methods with science and math. These courses combine topics traditionally found in separate introductory disciplinary courses to leverage the commonality of engineering problem-solving methods, design processes and mathematical applications. The MEFSC courses were developed and are currently taught by teams of faculty from several disciplines, to preserve their multidisciplinary nature. Engineering fundamentals are presented in the MEFSC courses from the first semester using a spiral curriculum approach, following the Constructivist Model of Jerome Bruner. ${ }^{7}$ In this approach topics are initially presented in a relatively simply manner and then revisited at a higher level of sophistication in subsequent courses, as the students' mathematical prowess develops. 


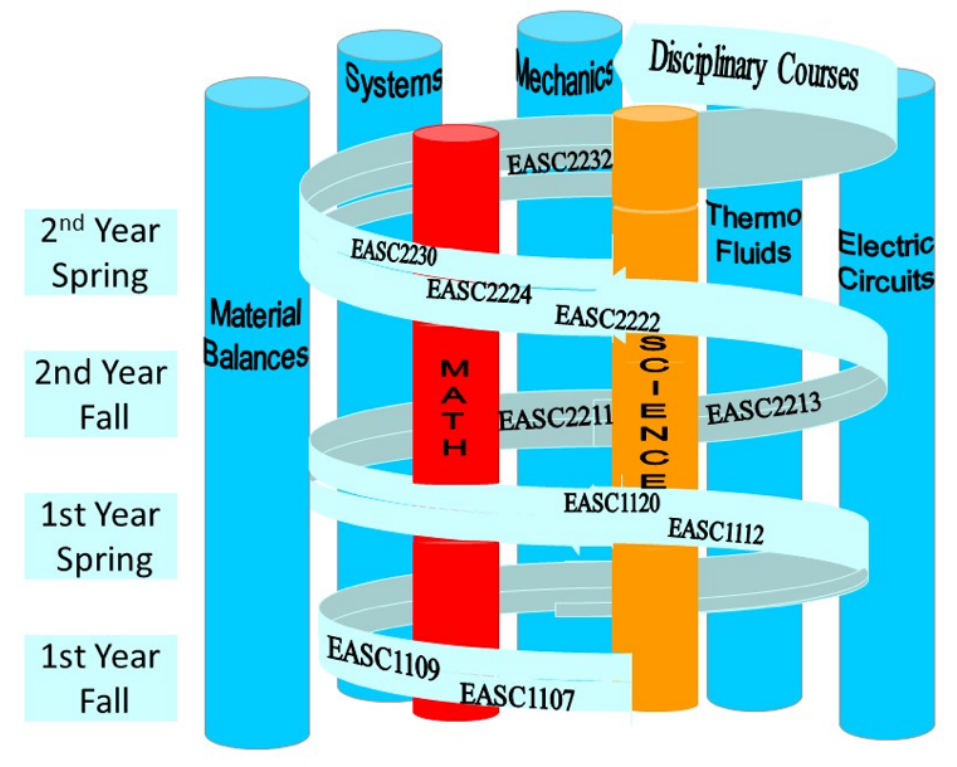

Figure 1. "Spiral" curriculum

The administration of the courses in the spiral curriculum is awkward within a standard discipline-based department structure and has been handled in an ad hoc manner for many years. Also, as further curricular innovations were developed and more and more faculty became involved in engineering education research, a need for leadership and coordination of activities emerged. In order to maintain the integrity of the curriculum it is essential that its management be separated from specific degree programs and yet faculty from those degree programs play a key role in the curriculum. Furthermore, it is important to link the curriculum to research and scholarship in engineering and applied science education to foster the use of the best pedagogical practices and to create visibility for the curriculum model.

Over the last several years, a few institutions in the country have established separate Departments of Engineering Education to spearhead innovative teaching practices and conduct research in engineering education. However, a separate Department of Engineering Education can become yet another "silo" within the engineering college with its own values that do not permeate into disciplinary departments. Faculty in this separate department can be viewed as "second class citizens" by faculty who conduct exclusively disciplinary research.

In order to address the leadership and coordination needs and address the problems identified above, the shared Department of Engineering and Applied Science Education (EASE) was created and became effective in August 2015. The EASE department draws faculty from existing disciplinary programs. Because faculty in the shared department also participate in deliberations within disciplinary programs, they can influence the penetration of values and pedagogical initiatives within those programs. The shared department provides a means to administer the "spiral" curriculum courses and the General Engineering program that are not owned by any one program or department. Faculty in the shared department have the flexibility to perform research in engineering education as well as in their disciplines, thereby keeping them connected to their disciplines. Also, some of the best instructors coming together from different programs to deliver the "spiral" curriculum sends the important message to students that the early year courses are important to the college. 


\section{Structure and Governance}

Ten faculty members from the college chose to participate in the shared department, with the breakdown shown in Table 1 . They elected a senior faculty member whose primary appointment is in the Department of Chemistry and Chemical Engineering as the first chair of the department. The chair is actively involved in engineering education research.

Table 1. Faculty Participants in Shared Department of Engineering and Applied Science Education

\begin{tabular}{|l|l|}
\hline Home Program & Participating Faculty \\
\hline Chemical Engineering & 1 full professor \\
\hline Chemistry & 1 non-tenure track lecturer (applied science education focus) \\
\hline Civil Engineering & 1 full professor, 1 assistant professor (sustainability focus) \\
\hline Electrical Engineering & 1 full professor \\
\hline Industrial and Systems Engineering & 1 associate professor \\
\hline Mechanical Engineering & 1 associate and 2 assistant professors \\
\hline Other & 1 non-tenure track instructor dedicated to EASC (spiral) courses \\
\hline
\end{tabular}

EASE faculty are required to commit $20 \%$ of their time to engineering education activities. This includes teaching at least one EASC course each year, and involvement in engineering and applied science education scholarship and/or EASE curricular initiatives. The chair of EASE discusses the allocation of time for subsequent years with each faculty member at the end of each spring semester, in consultation with the chair of their primary department, and makes adjustments as needed.

All of the faculty listed in Table 1 have voting rights in the shared department and act as the "academic unit" charged with responsibility for the "spiral" curriculum and the General Engineering program. They are responsible for maintaining and improving the courses, and liaising with the programs that require these courses. An EASE curriculum group coordinates and reviews course assessments and other activities.

\section{Representation in College Committees}

The University of New Haven requires that faculty committees at the college level have at least five members and have representation from each department. Currently, all college committees have a representative from each of the four disciplinary departments and one from EASE. Since members of EASE also are members of disciplinary departments, elections are coordinated to avoid the same faculty member from being elected by both a disciplinary department and EASE.

\section{Annual Reviews, Tenure and Promotion}

The tenure home of faculty belonging to the EASE department lie in their disciplinary departments. The chair of the EASE department has the responsibility to review the teaching performance of faculty teaching the "spiral" curriculum (EASC) courses, and sharing their performance, together with contributions and performance in engineering education research, with the chairs of their disciplinary departments. He will seek input from the curriculum group as needed. He will prepare an assessment regarding teaching, research and service related to engineering education and EASC courses for a faculty member applying for tenure and/or promotion and have this ratified by all tenured faculty in the EASE department. This assessment 
will be provided to the chair of the primary department of the candidate and will be included in the candidate's T\&P packet.

\section{Activities and Initiatives}

In addition to administering the "spiral" curriculum, the shared department has implemented two major college-wide curricular initiatives, several co-curricular activities, and faculty training as described below.

- With funding from the Davis Educational Foundation, an integrated approach to developing technical communication skills has been implemented across all engineering and computer science programs. The effort includes a 1-credit online course closely coupled with a freshman on-ground course, and e-learning modules integrated into third year laboratory courses and fourth year senior design courses.

- With funding from the Kern Family Foundation, 10 e-learning modules targeted at developing an entrepreneurial mindset in all engineering and computer science students have been developed and integrated into existing courses. Over the next year 8 more elearning modules will be developed. These modules have been deployed at 25 institutions around the country impacting more than 2000 students.

- The engineering freshman Living Learning Community was transformed to an Entrepreneurial Engineering Living Learning Community, with programming targeted at stimulating entrepreneurial thinking.

- Extracurricular activities such as 24-hour imagination quests, startup weekends and a 10day summer immersive design experience were conducted by faculty.

- Faculty development workshops on project-based, collaborative, and entrepreneurially minded learning were conducted by EASE faculty for other faculty in the college.

- Several EASE faculty participated twice to submit proposals to NSF's Revolutionizing Engineering Departments (RED) solicitation. While unsuccessful in securing a grant, the faculty were gratified to receive very positive feedback from external reviewers providing validation of their work.

\section{Potential Impact on Underrepresented Students and Faculty}

The shared department should be effective in addressing several issues that have been identified as barriers to participation of women and minorities in engineering fields. In particular, women and minorities have been deterred from entering engineering because of the relatively few faculty role models and the perception of engineering as a competitive rather than collaborative endeavor. ${ }^{8}$ It is also worth noting that $50 \%$ of the ten faculty in the EASE department are women, a percentage that is much higher than the percent of female faculty in the disciplinary departments. As the college recruits new faculty during the coming years, it will be interesting to observe if more women and minority faculty are attracted to the college due to the opportunity to participate in the shared department. Engineering education research is perceived to be more collaborative and less competitive than disciplinary engineering research ${ }^{9}$ and collaborative activity is more attractive to underrepresented groups. ${ }^{8,10}$ Since the faculty in the shared department have primary responsibility for first and second year engineering courses, the collaborative culture they establish should contribute to an environment that is more attractive to women and minority groups, who are often attracted to professions perceived as helping people. 


\section{Shared Department of Entrepreneurship and Innovation}

\section{The Need}

Curriculum and activities related to entrepreneurship and innovation are picking up steam around the country. These activities are typically housed within an engineering or business college, or as standalone centers or institutes. In August 2016, the College of Engineering and the College of Business at the University of New Haven proposed forming a university-wide shared Department of Entrepreneurship and Innovation. The goal was to build a comprehensive, collaborative and competitive Entrepreneurship and Innovation (E\&I) program with a national reputation as best-in-class. This will be done by fostering innovation and infusing aspiring entrepreneurs with a sense of the possible. Through rigorous coursework, start-up and business plan competitions, extensive networking and mentorship, and hands-on learning experiences, students will develop an innovative mindset vital to entrepreneurship and intrapreneurship.

The E\&I department was approved in December 2016 and provides a home for interdisciplinary curriculum in entrepreneurship and innovation, a center for entrepreneurship and innovation, and co-curricular programing. By forming this as a shared university department, an interdisciplinary program that is not rooted in a college silo was established.

\section{Structure and Governance}

Membership in the E\&I department consists of a combination of full- and part-time faculty with participation from departments across the university. The deans of engineering and business jointly appoint faculty to be members of the E\&I department for up to three years. Appointments are renewable. Full-time tenured, tenure-track, and non-tenure track faculty in addition to practitioners-in-residence, executives-in-residence and adjuncts may request a joint appointment to the E\&I department. The faculty member's college dean determines the share of their load dedicated to the E\&I department.

Minimum expectations of participation in the department include:

- Active and regular participation in co-curricular initiatives (startup weekends, pitch competitions, business plan competition, hack-a-thon, etc.),

- Contribution to the shared department's scholarship, and/or,

- Development and delivery of department curriculum.

The distribution of faculty in the department by college at the time it was formed is shown in Table 2. All full-time faculty in the department have voting rights and they elected a chair whose primary appointment is in the Department of Mechanical and Industrial Engineering. In addition to the chair, who guides curricular matters, a director, jointly appointed by the deans of engineering and business, manages the co-curricular activities of the department. More faculty from colleges outside engineering and business are being actively recruited. The department serves as the "academic unit" with jurisdiction over entrepreneurship and innovation courses that will have the ENTP prefix. To minimize committee service responsibilities for faculty, the E\&I department does not require faculty representation in college or university standing committees.

Table 2. Faculty Participants in Shared Department of Entrepreneurship and Innovation

\begin{tabular}{|l|l|}
\hline Home College & Participating Faculty \\
\hline Engineering & 1 full, 4 associate, and 3 assistant professors \\
\hline Business & 2 full, 1 associate, 1 assistant, and 1 practitioner-in-residence \\
\hline Arts and Sciences & 1 associate professor \\
\hline
\end{tabular}




\section{Curriculum}

The ENTP curriculum will emerge from courses in different colleges. A course entitled "Business Fundamentals and Entrepreneurship for Engineers and Scientists" was developed and offered for the first time in spring 2017 by the College of Engineering. This course was piloted as a special topics course, but will become one of the ENTP courses. Courses in the College of Business that are likely to be recast as ENTP courses include Entrepreneurship, Business Planning and Modeling, and New Venture Management. Once approved by the E\&I department, each ENTP course will be assigned to a "custodial college" and the curriculum committee in that college will approve the course and forward it to the university curriculum committee.

\section{Annual Reviews, Tenure and Promotion}

The tenure home of faculty belonging to the E\&I department lie in their disciplinary departments and respective colleges. The chair of the E\&I department has the responsibility to review the teaching performance of faculty teaching ENTP courses, and sharing their performance, together with contributions and performance in E\&I co-curricular activities and scholarship, with the chairs of their disciplinary departments. He will prepare an assessment regarding teaching, research and service related to entrepreneurship and innovation and ENTP courses for a faculty member applying for tenure and/or promotion. This assessment will be provided to the chair of the primary department of the candidate and will be included in the candidate's T\&P packet.

\section{Activities and Initiatives}

The shared E\&I department has accomplished the following during its short existence:

- An advisory board to oversee the activities of the department has been set up. The board currently consists of six people from business and engineering companies, the deans of the business and engineering colleges, five faculty members, and two staff members from the university's Development Office.

- About 70 students from around the university participated in a "startup weekend" held on September 16-18, 2016. Approximately $\$ 12,000$ in funding was secured from university alumni and friends.

- A "Business Plan Bootcamp" was offered as a formal 1-credit course in fall 2016 and 8 students enrolled for it. The course was taught by two adjunct instructors who both have extensive business experience.

- A new course entitled "Business Principles and Entrepreneurship for Engineers and Scientists" was developed in fall 2016 and taught in spring 2017 by an adjunct instructor with extensive business experience. Fifteen engineering students are enrolled in this course. The course will integrate the following five short e-learning modules developed at the University of New Haven through a grant funded by the Kern Family Foundation:

- Financing a business

- Developing a business plan that addresses stakeholder interests, market potential and economics

- Role of product in value creation

- Adapting a business to a changing climate

- The elevator pitch: advocating for your good ideas 
- A New Venture Pitch Competition was conducted in spring 2017. The following four 2hour boot camps were offered to students as a part of this competition:

- Ideation

- Sales and marketing

- Legal, finance and operations

- Pitch perfect

Prize money for the top three teams was sponsored by a donor.

During the coming year, the following activities are planned:

- Development of additional courses related to entrepreneurship and innovation

- Creation of a minor in Entrepreneurship

\section{Shared Department of Health Sciences}

\section{The Need}

The need to create a shared Department of Health Sciences at the University of New Haven stemmed from both a need for a new approach to health-related education and a tactical goal of unifying existing health programming. Health sciences professions, faculties, and schools have grown at a rapid pace in the last decade, ${ }^{11}$ yet the University of New Haven has neither clinical programs nor a College of Health Sciences. The university has at least 8 health-related undergraduate and graduate programs in each of its four colleges including biomedical engineering, pre-medicine, paramedicine and others. However, the institution had no structure by which these faculty could collaborate on new curriculum, grants, or projects. Creating new academic programs and updating pedagogy across the university's health programs required an institutional home to bring these disparate faculty together. New programs developed by the shared department would have the potential to attract new student populations to the university as well.

\section{Structure and Governance}

From 2014-2016, faculty interested in health sciences gathered, rather informally, as a way to build consensus and common ground. Approximately 25 faculty members with representation from the engineering, natural sciences, social sciences, business, and criminal justice faculties constituted the core group.

In December 2016, the shared Department of Health Sciences was officially chartered as a university-wide department with the ability to offer joint appointments to full-time faculty members at the university on an annually renewable basis. Faculty were invited to join the department after consultation with the dean of the college where they had their primary academic appointment. Renewal of membership was based on active attendance and participation in departmental meetings, contributions to department activities and events, and/or continued scholarship and activity in health-related research and projects. The distribution of faculty in the department at the time of its founding is shown in Table 3.

The department chair was elected from among the core faculty for a 3-year term and is an associate professor in the Health Care Administration program in the College of Business. The chair reports annually to a steering committee comprised of all the college deans and the provost. The department chair's college was appointed to be the custodial college for the purposes of 
internal administrative review and curriculum oversight. If a faculty member from a different college is elected as chair in the future, then the custodial college would change.

Table 3. Faculty Participants in Shared Department of Health Sciences

\begin{tabular}{|l|l|}
\hline Home College & Participating Faculty \\
\hline Engineering & $\begin{array}{l}\text { 2 full professors, 2 assistant professors, 1 non-tenure } \\
\text { track professor }\end{array}$ \\
\hline Business & 2 full, 1 associate, 1 assistant professor \\
\hline Arts and Sciences & $\begin{array}{l}1 \text { full professor, 6 associate professors, 5 assistant } \\
\text { professor, and 2 non-tenure track professors }\end{array}$ \\
\hline Criminal Justice & $\begin{array}{l}1 \text { full professor, 1 associate professor, 1 assistant } \\
\text { professor, 1 non-tenure track professor }\end{array}$ \\
\hline
\end{tabular}

\section{Curriculum}

Interprofessional approaches to health professional education are now standard in healthcare. ${ }^{12}$ The Institute of Medicine Global Forum on Health Professional Education concluded in 2016 that health professional education ought to be not only interprofessional but also competency based. ${ }^{13}$ The Department of Health Sciences faculty embraced the need for these curricular innovations. In fall 2016, the department created and approved a new Bachelor of Science degree in Health Sciences designed using this interprofessional and competency based approach. The custodial college curriculum committee then reviewed the proposal and routed it through the university's standard curriculum review process.

\section{Annual Reviews, Tenure and Promotion}

The shared Department of Health Sciences offers only secondary appointments to faculty at the university and therefore is not primarily responsible for annual reviews of faculty and does not participate officially in the tenure and promotion process for its faculty. However, faculty are encouraged to report their contributions to the shared department in their annual faculty activity reports and the department chair will provide a letter to faculty members for their tenure and promotion package.

\section{Activities and Initiatives}

The Department of Health Sciences has engaged in a wide range of activities and initiatives aimed at students and faculty across the university. These include:

- Creation of a Health Sciences advisory board, comprised entirely of University of New Haven alumni, to foster industry relationships for internships and mentoring programs

- Creation of a new BS degree in Health Sciences degree anticipated to launch in fall 2017

- Creation of a new Pre-Health Professions advising program for pre-professional students

- Development of a business plan for a new Health Analytics degree developed in collaboration with the Colleges of Business and Engineering

- Development of a business plan for a new MS in Physician Assistant Studies program

- Launching of a Health Sciences speaker series for undergraduate students

- Reinventing the Health Sciences Living Learning Community with the Office of Residence Life 


\section{Potential Impact for Interprofessional Health Education}

The BS in Health Sciences degree is the first new academic program housed entirely within the Department of Health Sciences. It is anticipated that other programs will quickly follow in development and implementation given this program's success to date. At the core of this degree program is a health sciences core curriculum that is competency based, skills focused, and interprofessional. It is anticipated that this core will become part of the academic offerings of other health-related undergraduate and graduate programs at the University of New Haven.

Moreover, activity is already underway to create $4+1$ programs between the BS in Health Sciences and the MS in Biomedical Engineering and other graduate programs to create even more interdisciplinary and interprofessional training opportunities for students.

\section{Lessons Learned and Challenges}

The following are the lessons learned and challenges encountered in the creation and operation of the three new shared departments at the University of New Haven:

- The shared departments have proven to be a successful approach for unifying diverse faculty and programs under a single administrative unit for the purposes of building new curricula and programs. Institutions considering new colleges, programmatic reorganizations, or highly interdisciplinary ventures might wish to adopt a shared department model. Such a department can serve as a pilot to test for viability of a new institutional structure or a neutral space for new ideas to percolate and develop outside disciplinary or even college boundaries. Challenges and constraints of such an approach include the time and effort necessary to form collaborative relationships across disciplinary boundaries and the considerable creativity and flexibility required working outside conventional administrative and reporting structures to achieve departmental objectives.

- It is important to allow sufficient time for the shared departments to evolve. It took one or more years to move from concepts to establishing each shared department with participating faculty. For example, it will take another year to create a minor and a major in entrepreneurship and innovation.

- Throughout the early development of the shared departments, administrative leadership was critical. Champions at the level of deans or the provost were essential for success. Institutional leaders needed to assure that the shared departments would receive sufficient resources. In the case of the Health Sciences department, a faculty champion was able to move the effort forward.

- Faculty concerns regarding time commitments for meetings related to both their primary disciplinary departments and the shared departments needed to be addressed. Deans needed to assure the faculty that the chairs of all departments would have focused and concise meetings that used time efficiently. For example, the EASE department established a small curriculum group to handle routine course revisions and approvals, thereby not saddling all faculty with these issues.

- Faculty time had to be appropriately allocated so that they could teach courses in their disciplines as well as in the shared departments. Teaching loads were negotiated between the chairs of the respective departments, with appropriate intervention by the deans as needed. Flexibility was created by allowing the time allocated by each faculty member to one or more shared department to change from year to year. 
- Student credit hours generated by a faculty member are assigned to his/her primary disciplinary department. This helps alleviate concerns by disciplinary department chairs regarding the allocation of faculty time toward the shared departments.

- Faculty concerns regarding the value of their work for the shared departments toward tenure and promotion considerations needed to be addressed.

- The criteria for tenure and promotion in the College of Engineering had previously been broadened so that scholarship related to engineering and applied science education (including scholarship related to entrepreneurship and innovation education) was considered to be on par with scholarship in technical disciplines.

- Courses in the "spiral" curriculum are taken by most majors in the College of Engineering and chairs of disciplinary departments were generally amenable to their faculty teaching EASC courses. Disciplinary departments are expected to contribute faculty FTE's to teach EASC courses based on the proportion of EASC credits taken by their majors.

- Language matters. For example, to attract students from across the university to participate in co-curricular activities of the Entrepreneurship and Innovation Department, the words "entrepreneurship" and "business" in the titles of activities are minimized. These words are often associated with the business college, so special care is needed so that students do not think that the co-curricular activities are targeted primarily to business majors.

\section{References}

1. National Academy of Engineering (2005). Educating the engineer of 2020: adapting engineering education to the new century. Washington, DC: National Academies Press.

2. Collura, M., Daniels, S., Aliane, B., and Nocito-Gobel, J. (2004). "Development of a multidisciplinary engineering foundation spiral." Proceedings, ASEE Annual Conference, Session 2630.

3. Collura, M., Daniels, S., Aliane, B., and Nocito-Gobel, J. (2004). "Learning the methods of engineering analysis using case studies, Excel, and VBA." Proceedings, ASEE Annual Conference, Session 1520.

4. Collura, M., Daniels, S., Harding, W., and Nocito-Gobel, J. (2006). "A multidisciplinary modeling course as a foundation for study of an engineering discipline." Proceedings, ASEE Annual Conference, Session 1693.

5. Broderick, G., Collura, M., Daniels, S., Nocito-Gobel, J., and Stanley, R. (2007). "Civil and mechanical engineering students learning mechanics in a multidisciplinary engineering foundation spiral." Proceedings, ASEE Annual Conference, Session 1430.

6. Collura, M., Daniels, S., Harding, W., and Nocito-Gobel, J. (2007). "The current generation of integrated engineering curriculum." Proceedings, ASEE Annual Conference, Session 1430.

7. Bruner, J. (1966). Toward a theory of instruction. Cambridge, MA: Harvard University Press.

8. Blue, C. E., Blevins, L. G., Carriere, P., Gabriele, G., Kemnitzer, S., Rao, V., and Ulsoy, G. (2005). "The engineering workforce: current state, issues and recommendation." Report to the Assistant Director of Engineering, National Science Foundation. 
9. Xian, H., and Madhavan, K. (2012). "A quantitative study of collaboration patterns of engineering education researchers", Proceedings, ASEE Annual Conference.

10. Fortenberry, N., and Jepson, J. (2008). "General trends in engineering education support the participation of women." Proceedings, ASEE Annual Conference.

11. University of California Office of the President (2013). "A new era of growth: a closer look at recent trends in health professional education." <http://www.ucop.edu/uc-health/_files/anew-era-of-growth_may2013.pdf $>$. Accessed on January 29, 2016.

12. Jensen, G. M, Harvan, R. A., and Royeen, C. B. (2008). "Interprofessional education: context, complexity and challenge." In Leadership in Interprofessional Health Education and Practice. Burlington, MA: Jones and Bartlett..

13. Cuff, P. A. (ed.) (2016). "Envisioning the future of health professional education." Workshop Summary, Global Forum on Innovation in Health Professional Education, Washington, D.C.: The National Academies Press. 